DOI: $10.36910 / 6775-2524-0560-2020-40-02$

УДК: 621.317 .3

Гнатченко Дмитро Анатолійович, провідний науковий співробітник випробувальної лабораторії https://orcid.org/0000-0002-5602-9318

Український науково-дослідний інститут спеціальної техніки та судових експертиз Служби безпеки України

\title{
СИСТЕМИ АВТОМАТИЗОВАНОГО ПРОЕКТУВАННЯ ЯК ОДИН ІЗ ІННОВАЦЙНИХ НАПРЯМКІВ У СТВОРЕННІ РАДІОЕЛЕКТРОННОЇ АПАРАТУРИ
}

Гнатченко Д. А. Системи автоматизованого проектування як один із інноваційних напрямків у створенні радіоелектронної апаратури. У статті розглянуто сучасний стан, наведено основні види та визначено тенденції розвитку систем автоматизованого проектування радіоелектронної апаратури в провідних країнах світу.Встановлено, що використання сучасних систем автоматизованого проектування дозволяє об'єднати проектування і виробництво в один процес та скоротити час й вартість створення радіоелектронної апаратури.Також проаналізовано сучасний стан розроблення, використання $\mathrm{i}$ перспективи розвитку систем автоматизованого проектування радіоелектронної апаратури в Україні.

Ключові слова:радіоелектронна апаратура, системи автоматизованого проектування, тенденції, шляхи та перспективи розвитку, ІТ-технології, інновації.

Гнатченко Д. А. Системы автоматизированного проектирования как одно из инновационных направлений в создании радиоэлектронной аппаратуры. В статье рассмотрено современное состояние, приведены основные виды и определены тенденции развития систем автоматизированного проектирования радиоэлектронной аппаратуры в ведущих странах мира. Установлено, что использование современных систем автоматизированного проектирования позволяет объединить проектирование и производство в один процесс и сократить время и стоимость создания радиоэлектронной аппаратуры. Также проанализировано современное состояние разработки, использования и перспективы развития систем автоматизированного проектирования радиоэлектронной аппаратуры в Украине.

Ключевые слова: радиоэлектронная аппаратура, системы автоматизированного проектирования, тенденции, пути и перспективы развития, ИТ-технологии, инновации.

Hnatchenko D. A. Automated design systems as one of the innovative directions in the creation of electronic equipment. The article considers the current state, presents the main types and identifies trends in the development of computer-aided design of electronic equipment in leading countries. It is established that the use of modern computer-aided design systems allows to combine design and production into one process and reduce the time and cost of creating electronic equipment. The current state of development, use and prospects of development of computer-aided design systems for electronic equipment in Ukraine are also analyzed. innovations.

Keywords: electronic equipment, computer-aided design systems, trends, ways and prospects of development, IT technologies,

Постановка проблеми.Останні роки 3 метою задоволення постійно зростаючих потреб суспільства радіоелектронна апаратура (РЕА)ускладнюється та набуває багатофункціональності, що призводить до іiї постійного удосконалення. Сучасна РЕА- цевзаємопов'язана множина пристроїв, вузлів та модулів, щофункціонуютьза різними фізичними принципами. Модернізація сучасної РЕА передбачає застосовування знань та вмінь, навичок з різних сфер науки і техніки, що істотно ускладнює та збільшує терміни на ії створення. Тому актуальним $є$ завдання пошуку шляхів спрощення цього процесу на основі використання систем автоматизованого проектування (САПР)PЕА [1].

Аналіз останніх досліджень і публікацій.Питанням, що пов'язані з САПР присвячено велику кількість робіт, наприклад [2-14]. Однак вони не враховують специфіки проектування та експлуатації PEA в Україні.

Метою дослідженняє обгрунтування процесу використання САПР як одного із інноваційних напрямків у створенні РЕА. Реалізація поставленої мети передбачає виконання наступнихзавдань дослідження:аналіз сучасного стану, розгляд основних видів та визначення тенденцій розвитку САПР PEA в провідних країнах світу; аналіз сучасного стану розроблення, використання і перспективи розвитку САПР РЕА в Україні.

Виклад основного матеріалу дослідження.Розвиток вітчизняних підприємств РЕАпотребує пошуку нових способів досягнення світових норм конкурентоспроможності PЕА. Найбільш актуальним в світі підходом $є$ запровадження сучасних IT-технологій в рамках інноваційної діяльності підприємства. Якщо сучасні підприємства (як державні, так і приватні) не будуть випускати РЕА найвищої якості за умови нижчої ціни і в коротші терміни, то, відповідно, не зможуть існувати в сучасних ринкових умовах економіки. Використання сучасних IT-технологій дозволяє об'єднати проектування і виробництво в один процес та скоротити час й вартість створення РЕА. Для цього і використовують САПР. 
САПР - це комплекс засобів автоматизації процесу проектування (який пов'язаний 3 підрозділами проектної організації та колективом фахівців-проектувальників) та відповідне програмне забезпечення, що призначені для автоматизованого проектування продукції [12].

Далі в статті розглянемо сучасний стан, основні види, тенденції розвитку САПР РЕА в провідних країнах світу та сучасний стан розроблення, використання і перспективи розвитку САПР РЕА в Україні.

Сучасний стан САПР РЕА в провідних краӥнах світу.Основними світовими виробниками САПР $є$ такі компанії як: AutodeskInc., DassaultSystemes, TrimbleInc., GstarsoftCo. Ltd., 3D SystemsCorporation, AvevaGroup PLC, Hexagon AB, IronCAD LLC i Siemens AG. Кругова діаграма розподілу виробників САПР, що можуть бути використанні під час створення РЕА наведена на рис. 1.

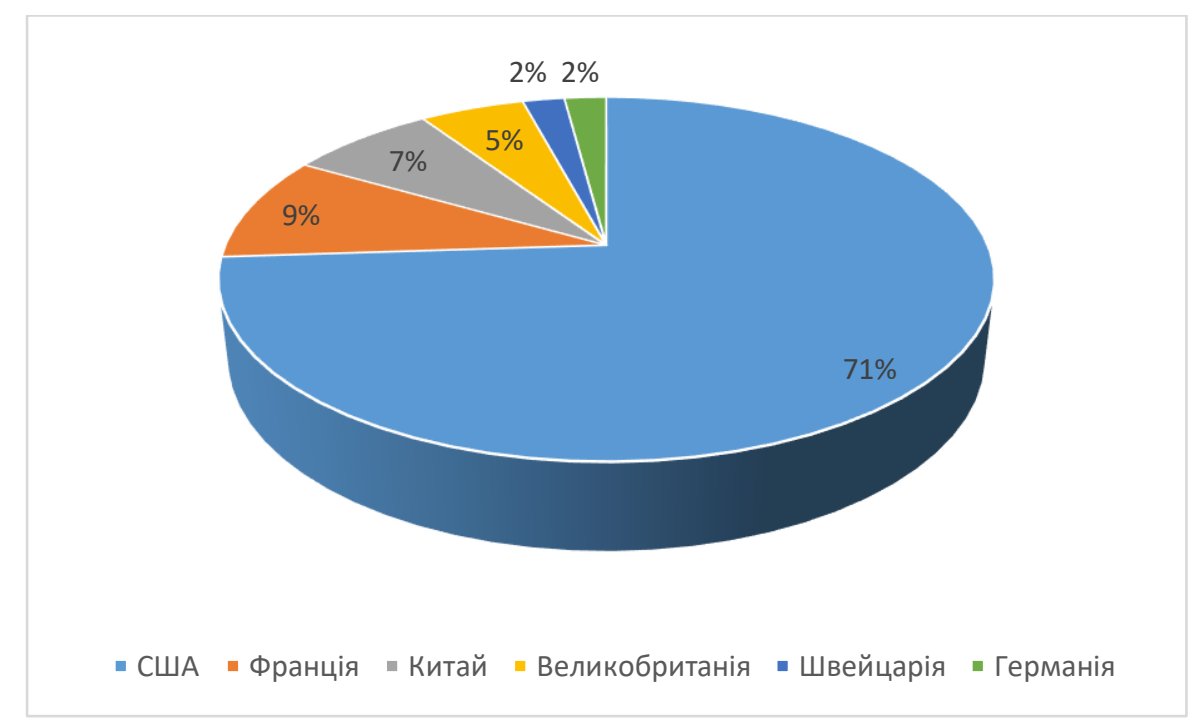

Рис. 1. Розподіл виробників САПР, що можуть бути використанні під час створення РЕА

Широке застосування IT-технологій призвело до істотних змін в сфері автоматизації проектування РЕА. У світібуло створено нові сучасні програмні комплекси (це САПР), що зменшують терміни та витрати на розроблення нових проектів, забезпечують високу якість проектних рішень $\mathrm{i}$ підвищення ефективності роботи фахівців [7]. На рисунку 2 наведено прогноз динаміки світового ринку САПР РЕА.

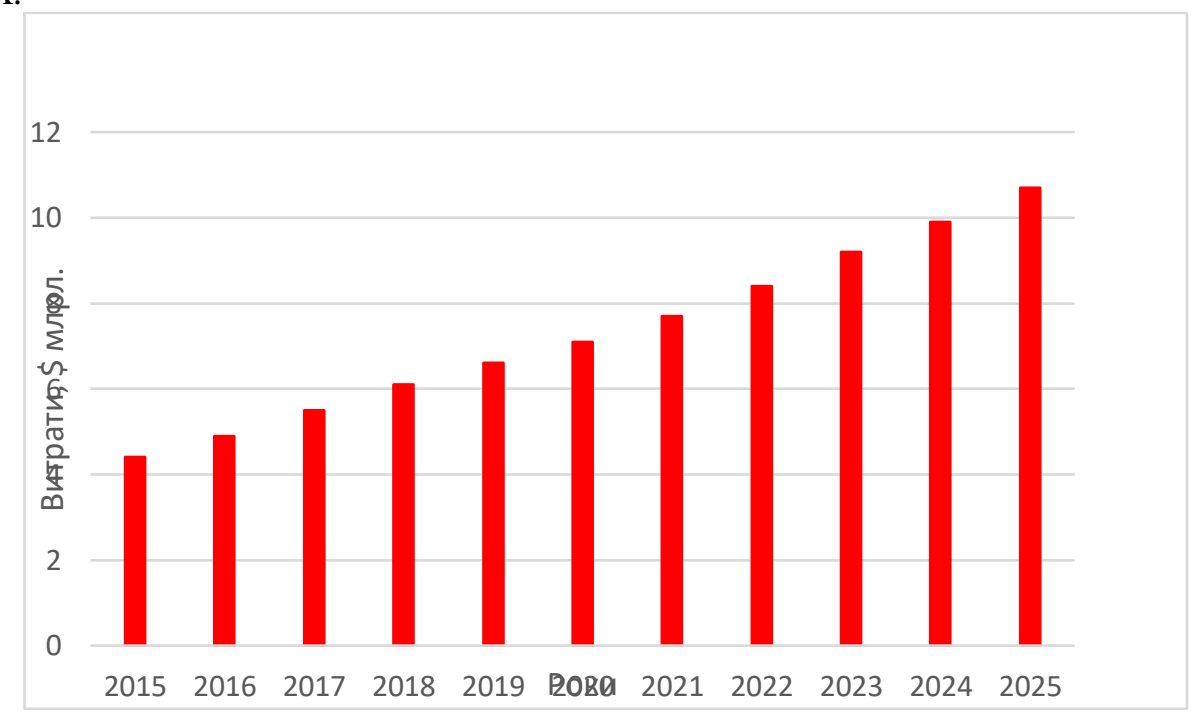

Рис. 2. Прогнозування динаміки світового ринку САПР РЕА, \$ млрд.

На сьогодні, найбільш відомими САПР є:

- AutoCAD LT, AutoCADMechanical, T-FLEX CAD 2D, nanoCADМеханика, КОМПАС-ГРАФИК. Ці САПР використовуються для двовимірних креслень (CAD);

- SolidWorks, SolidEdge, T-FLEX CAD 3D, Inventor, КОМПАС-3D. Ці САПР використовуються для твердотільного моделювання (CAD); CAM;

- ADEM, T-FLEX ЧПУ, Mastercam, SolidCAM, EdgeСАM. Сферою застосування цих САПР $є$ 
- Ansys, Nastran, APM WinMachine. Сферою застосування цих САПР є CAE;

- CATIA, NX, Pro/ENGINEER. Ці CAПР є інтегрованими, вони забезпечують весь цикл створення продукції від концептуальної ідеї до реалізації, а також, створюють проектно-технологічне середовище для одночасної роботи всіх учасників створення продукції.

Застосування цих САПР передбачається, як для масового, так і на штучного виробництва.

До найбільш відомих САПР, що використовуються для створення РЕА належать:

- SolidWorks - САПР, що забезпечує автоматичне проектування, інженерний аналіз и підготовкувиробництва виробів різної складності та призначення (розробник компанія“SolidWorksCorporation” (США));

MathCAD - інтегрована система для розв'язання математичних, інженерно-технічних і наукових задач;

Rhinoceros 3D - комерційне програмне забезпечення для тривимірного NURBS моделювання (розробник -RobertMcNeel\&Associates). Переважно використовується в промисловому дизайні, архітектурі, корабельному проектуванні, ювелірному та автомобільному дизайні, в CAD/CAM проектуванні.

САПР CATIA (ComputerAided Three-dimensionalInteractiveApplication) - це одна з САПР високого рівня, з такими складовими як системи автоматизованого проектування (CAD), технологічної підготовки виробництва (CAM) та інженерного аналізу (CAЕ). Вона включає в себе передовий інструментарій 3D-моделювання, підсистеми програмної імітації складних технологічних процесів, розвинені засоби аналізу і єдину базу даних текстової та графічної інформації. САПР САТІА дозволяє ефективно вирішувати всі завдання технічної підготовки виробництва - від концептуального проектування до розроблення креслень і специфікацій.

ANSYS - універсальна програмна система кінцево-елементного (МСЕ) аналізу.Існує i розвивається протягом останніх 30 років, є досить популярною у фахівців в області комп'ютерного інжинірингу та КЕ розв'язання лінійних і нелінійних, стаціонарних та нестаціонарних просторових задач механіки деформованого твердого тіла й механіки конструкцій. Моделювання та аналіз в деяких областях промисловості з іiі допомогою дозволяє уникнути дорогих і тривалих циклів розробки типу проектування - виготовлення - випробування.

Коротко зупинимося на основних складових (або підсистемах) САПР [10]:

- CAD (ComputerAidedDesign) - конструкторська підсистема призначена для автоматизації двовимірного і тривимірного проектування, створення необхідної конструкторської та виробничотехнологічної документації;

- CAE (ComputerAidedEngineering) - функціональна підсистема призначена для вирішення різного роду інженерних задач (наприклад, розрахунків, аналізу і моделювання фізичних явищ $\mathrm{i}$ процесів). Вона дозволяє проводити оцінювання поведінки імітаційної моделі технологічного процесу або об'єкту в реальних умовах експлуатації та доводить працездатність даної моделі без залучення суттєвих матеріальних та часових витрат;

- CAM (ComputerAidedModeling) - технологічна підсистема призначена для комп'ютеризованої підготовки виробництва;

- PDM (ProductDataManagement) - підсистема забезпечення єдиного інформаційного простору, як між структурними підрозділами проектувальної компанії, так і окремими проектувальниками;

- ERP (EnterpriseResourcePlanning) - підсистема для управління бізнес-процесами на підприємстві

- PLM (ProductLifecyleManagement) - підсистема забезпечення єдиного інформаційного простору на основі функціональних можливостей підсистем PDM і ERP.

Тенденщії розвитку САПР РЕА в провідних країнах світу.Основними тенденціями розвитку САПР РЕА, на наш погляд $є$ : постійне удосконалення апаратної складової САПР РЕА шляхом застосування архітектури RISC (та їй подібних), використання для проектування РEA мобільних пристроїв (наприклад, таких як планшети), використання альтернативних операційних систем, стрімкі темпи застосування хмарних технологій. Розглянемо кожну з них більш детально.

Постійне удосконалення апаратної складової САПР РЕА шляхом застосування архітектур подібних RISC. В результаті конкуренції в умовах сучасного ринку виникають різні архітектури, крім класичної Intel, наприклад архітектури ARM (Advanced RISC Machines). Практично всі сучасні пристрої малих габаритів 3 акумулятором оснащені центральними процесорами на базі ARM, але незабаром, вона буде використана і в стаціонарних персональних комп’ютерах.

Друга тенденція пов'язана із зростанням ринку мобільних пристроїв (зокрема, планшетів, подібних iPad). Наочно, що ці пристрої мають не тільки споживацьке застосування, а можуть бути 
використані і для корпоративного сектору і в тому числі для САПР РЕА. У сфері САПР (i, зокрема, САПР РЕА), особливо в умовах карантину, більша частка фахівців є мобільними - працюють дистанційно.Такі умови потребують зручнихмобільних пристроїв. У провідних проектних компаніях за кордоном, інженерні служби вже оснащені такими пристроями 3 відповідним програмним забезпеченням (наприклад, САПР-додатки на мобільних платформах AndroidGoogle i IOS Apple).

Використання альтернативних операційних систем стає більш нагальним у зв'язку появою таких операційних систем, як GoogleChrome OS. Особливо це стає актуальним коли GoogleChrome OS поєднується з хмарним трендом - OC Google.

Важливою тенденцією розвитку САПР РЕА $є$ “хмарне” проектування: дистанційне проектування та робота 3 даними, що розміщені на серверах в різних куточках світу. Цей процес здійснюється 3 різних пристроїв (стаціонарних або мобільних), що мають вихід в мережу інтернет. Сучасні хмарні технології дуже швидко набули розвитку в сегменті легких додатків і сервісів (наприклад, кіберспорт, споживчій сектор тощо).

На сьогодні можливо два варіанти інтеграції процесів пов'язаних з проектуванням РЕА на основі хмарних технологій. Перший варіант передбачає трансфер (перенесення) в хмарні сервіси всієї інфраструктури інженерних служб (в цьому випадку зникає необхідність в інженерному програмному забезпеченні на робочому місці). Для другого варіанту у проектувальника залишається інстальована САПР РЕА на його робочому місці і він з неї отримує доступ до різноманітних хмарних сервісів. Другий варіантдозволяе вирішувати завдання, що потребують потужного витрачання ресурсів, як апаратних, так і програмних. Для обох розглянутих варіантів хмарна взаємодія в рамках САПР РЕА можлива двома наступними способами. По-перше,відкрито, коли доступ до серверу, що розташованийу провайдера послуг, відкритий через інтернет, i, по-друге - в приватному порядку, коли сервер знаходиться на підприємстві та звернення до нього реалізовуються по закритій локальній мережі.

ВУкраїні та у колишніх членах СНД розвиток хмарних технологійу сфері САПР (i, зокрема, САПР РЕА) стримується необхідністю дотримуватися в дуже багатьох проектах зайвої таємності. Тому швидше за все саме приватні хмарні сервіси стануть найближчим часом найбільш популярними. Зараз хмарні технології - це не лише сучасні передові інформаційні технології, але і можливість створення та експериментування з новими інформаційними моделями.

Стан розроблення, використання та перспективи розвитку САПР РЕА в Україні.На сьогодні машино- та приладобудування $\epsilon$ невід’ємними від електроніки. Як відмічалося вище, що проектування РЕА вже неможливо без САПР. Якщо у державі немає власної САПР РЕА, то і відповідно у цій державі, як правило, немає і власного повноцінногопроцесу створення таких систем. В Україні практично не має сучасних напівпровідникових виробництв. Процес створенняРЕА, що базується на сучасних САПР, залежить від закордонних виробників[13] (див. рис. 1).

В Україні використовують в основному креслярські 2D-системи (AutoCAD, KOMПАC, T-flex тощо), програми для механічної обробки (MasterCAM, AlphaCAM, Техтран, ТІГРАС тощо). Програмні пакети об'ємного моделювання через їх високу вартість, підвищені вимоги до кваліфікації персоналу та складність освоєння застосовуються набагато рідше, хоча завдань, для вирішення яких необхідні саме 3D-системи, стає все більше[3]. Крім зазначених вище, в Україні є інтерес до наступних САПР: Siemens PLM Software (Unigraphics, NX, TeamCenter, Tecnomatrix), Autodesk (AutoCad, Inventor), DassaultSystemes (CATIA, SolidWorks, SIMULIA). 


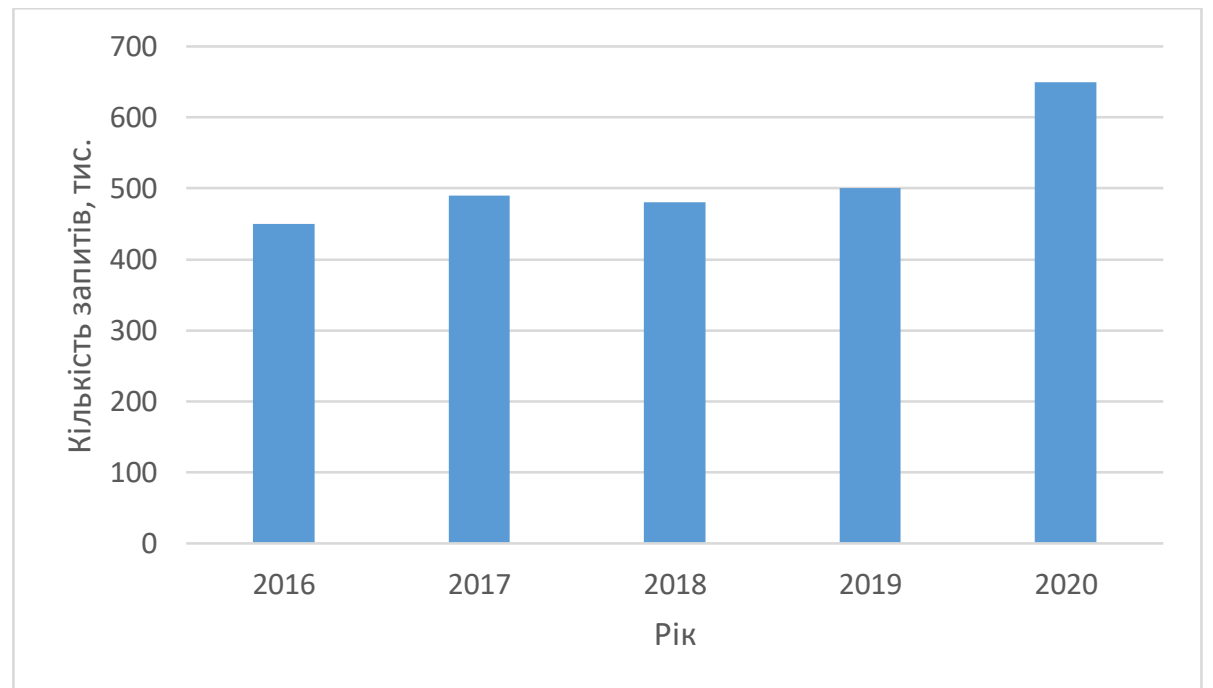

Рис. 3. Кількість запитів із України в пошуковій системі Google щодо CAПР AutoCAD

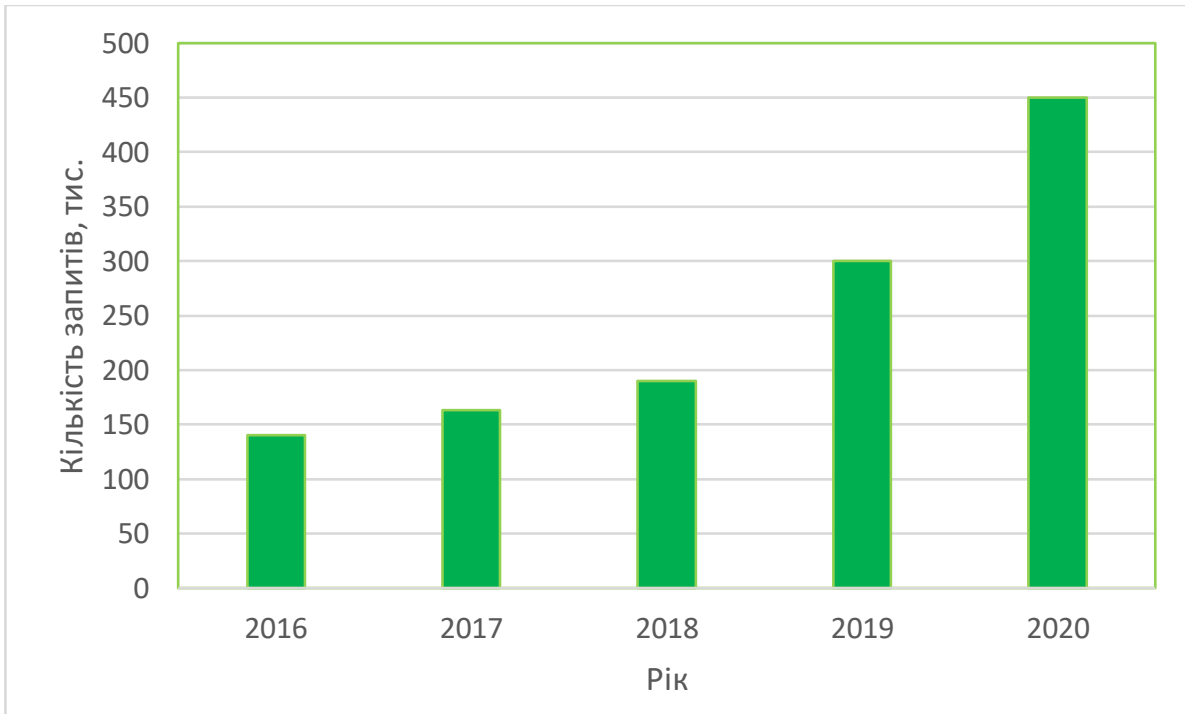

Рис. 4. Кількість запитів із України в пошуковій системі Google щодо САПР CATIA

На рисунках 3 та 4 показана динаміка запитів користувачів із України в пошуковій системі Google щодо CAПР AutoCAD та CATIA, відповідно.

Великі витрати на виробництво РЕА практично безпорадні без САПР, а більшу частку вартості РЕАзаймає вартість їх проектування. Покупку тимчасових ліцензій на використання закордонних САПР РЕА можуть собі дозволити тільки великі приватні (або державні) компанії і ці САПР зовсім недоступні для малих підприємств. Отже, потенціал України в розробці РЕА (і, відповідно, САПР PЕА)досить обмежений. Крім того, практично неорганізований процес створення РЕА в масштабах держави, що призвело до повної не конкурентоспроможності вітчизняних САПР РЕА.

Проблема в тому, що сучасну вітчизняну САПР РЕА швидко не зробиш. На створення сучасних зразків закордонних САПР пішли десятки років та тисячі висококваліфікованих високооплачуваних фахівців.На наш погляд, для вирішення цієї проблеми, необхідно повністю поміняти політику державного фінансування, перемістивши фокус з розрізнених проектів створення САПР РЕА на створення інфраструктури розроблення таких систем, що доступна для всіх підприємств України (3 різним правом власності). Такій підхід може бути реалізований шляхом виконання наступних дій:

- створення початкового варіанта інфраструктури для створення САП РЕА;

- сбір, оброблення та систематизація баз даних щодо досвіду створення українськими компаніями вітчизняної САПР РЕА;

- розроблення та подальша поступова реалізація дорожньої карти створення необхідної інфраструктури за допомогою нових українських розробок або закупівлі західних компонентів САПР PEA;

- формування державної програми для реалізації такої інфраструктури; 

програми.

- створення повністю української інфраструктури, включаючи САПР, на базі державної

Такий підхід суттєво дозволить знизити вартість та терміни створення РЕА. Безумовно, найскладнішим завданням є створення конкурентоспроможної САПР, але воно реалізуємо поступово (частками) і за досить тривалий час.

Висновки та перспективи подальших досліджень.Отже, у статті наведено обгрунтування процесу використання САПР як одного із інноваційних напрямків у створенні РЕА. Також розкрито сучасний стан САПР РЕА в провідних країнах світу, основні види цих САПР та тенденції їх розвитку. Проаналізовано сучасний стан розроблення та використання САПР РЕА в Україні і визначено перспективи їх розвитку. Подальшим актуальним напрямком дослідженьє розроблення комплексної методики проектування РЕА різноманітними САПР.

Список бібліографічного опису

1. Пономарьов Ю. В., Дячук О. Ю., Грабар І. Г. (2013). Методика проектування радіоелектронних пристроїв різноманітними системами автоматизованого проектування. Збірник наукових праць ЖВI НАУ, 7, 88-100.

2. Алексеев О. В., Головков, А. А. (2000). Автоматизация проектирования радиоэлектронных средств : учеб. пособ. для вузов. Москва: Высш. шк., 479 с.

3. Колодницький, М. М. (1999). Елементи теорії САПР складних систем : навч. посіб. Житомир : ЖІТІ, 512 с.

4. Пономарьов, Ю. В. (2006). Основи автоматизації проектування радіоелектронної апаратури. Система схемотехнічного моделювання Electronics Workbench. Житомир : ЖВIPE, 196 с.

5. Обзор программных продуктов электронного САПР. (2020). URL : http://pspicelib.narod.ru/01_modelirovanie/obzor_sapr.htm (Last accessed: 17.03.2020).

6. Хернитер Марк, Е. (2006). Multisim: Современная система компьютерного моделирования и анализа схем электронных устройств / пер. с англ. А. И. Осипова. Москва : Изд. дом ДМК-прес,. 488 с.

7. Разевиг, В. Д. (2001). Проектирование печатных плат в Р-САD 2001. Москва : Солон-Р, 560 с.

8. Заеленчец, А. С., Бутова, А. Л. (2016). Анализ и перспективы развития систем автоматизированного проектирования в строительстве. Молодой ученый, 63 (110.3), 21-23.

9. Астафьева, В. В. (2016). Компьютерное моделирование в России. Молодой ученый, 21 (125), 747-750.

10. Советов, Б. Я., Яковлев, С. А. (2001). Моделирование систем: учебник для вузов. Москва : Высшая школа, 320 с.

11. Дятлов М. Н., Юдкин И. Ю., Шляховский А. А. (2015). Тенденции развития современных интегрированных системи проектирования. Молодой ученый, 2 (82), 148-150.

12. Дятлов, М. Н., Федотов, М. Ю., Федотова, Н. В. (2013). Оптимизация времени проектирования с использованием современных машиностроительных САПР. Молодой учёный, 10 (1), 138-140.

13. Стемпковский, А. Л. (2015). Микроэлектронный САПР: вчера, сегодня, завтра. 29 июня. URL : http://isicad.ru/ru/articles.php?article_num=17837. (Last accessed: 17.03.2020).

14. Тошева М. Х., Худоёрова О. М., Азимова Д. Ю. (2016). Использование современных информационных технологий. Молодой ученый, 25 (129), 4-5.

\section{References}

1. Ponomarev Yu. V., Dyachuk O. Yu., Grabar IG (2013). Methods of designing electronic devices by various computer-aided design systems. Collection of scientific works of ZhVI NAU, 7, 88-100.

2. Alekseev O. V., Golovkov, A. A. (2000). Automation of designing radio-electronic means: textbook. manual. for universities. Moscow: Higher. shk., 479 p.

3. Kolodnitsky, M. M. (1999). Elements of the theory of CAD of folding systems: navch. posib. Zhitomir: ZhITI, 512 p.

4. Ponomarov, Yu. V. (2006). Basics of automation of radioelectronic equipment design. System of circuitry model Electronics Workbench. Zhitomir: ZhVIRE, $196 \mathrm{p}$.

5. Review of software products of electronic CAD. (2020). URL: http://pspicelib.narod.ru/01_modelirovanie/obzor_sapr.htm (Last accessed: 03/17/2020).

6. Herniter Mark, E. (2006). Multisim: Modern system of computer modeling and analysis of circuits of electronic devices / per. from English A.I. Osipov. Moscow: Publishing house. house DMK-pres ,. $488 \mathrm{~s}$.

7. Razevig, V.D. (2001). Design of printed circuit boards in P-CAD 2001. Moscow: Solon-R, 560 p.

8. Zaelenchets, A. S., Butova, A. L. (2016). Analysis and prospects for the development of computer-aided design systems in construction. Young Scientist, 63 (110.3), 21-23.

9. Astafieva, V.V. (2016). Computer modeling in Russia. Young Scientist, 21 (125), 747-750.

10. Soviets, B. Ya., Yakovlev, S. A. (2001). System modeling: a textbook for universities. Moscow: Higher school, 320 p.

11. Dyatlov M.N., Yudkin I. Yu., Shlyakhovsky A.A. (2015). Development trends of modern integrated design systems. Young Scientist, 2 (82), 148-150.

12. Dyatlov, M.N., Fedotov, M. Yu., Fedotova, N.V. (2013). Optimization of design time using modern engineering CAD systems. Young Scientist, 10 (1), 138-140.

13. Stempkovsky, A. L. (2015). Microelectronic CAD: yesterday, today, tomorrow. June 29 . URL: http://isicad.ru/ru/articles.php?article_num=17837. (Last accessed: 03/17/2020).

14. Tosheva M. Kh., Khudoyorova O. M., Azimova D. Yu. (2016). Use of modern information technologies. Young Scientist, 25 (129), $4-5$. 